\title{
Bilingualism in Contemporary Ukraine
}

\author{
Shuijing Lin \\ College of Foreign Languages, Nankai University, Tianjin, China \\ Email: 981285754@qq.com
}

How to cite this paper: Lin, S.J. (2020) Bilingualism in Contemporary Ukraine. Open Access Library Journal, 7: e6647. https://doi.org/10.4236/oalib.1106647

Received: July 23, 2020

Accepted: August 17, 2020

Published: August 20, 2020

Copyright $\odot 2020$ by author(s) and Open Access Library Inc.

This work is licensed under the Creative Commons Attribution International License (CC BY 4.0).

http://creativecommons.org/licenses/by/4.0/

\begin{abstract}
Ukraine is a bilingual country with the longstanding coexistence of two languages, namely Ukrainian and Russian. A thorough understanding of the cause and history behind its contemporary language situation could contribute to further research about Ukrainian culture.
\end{abstract}

\section{Subject Areas}

Linguistics

\section{Keywords}

Bilingualism, Ukraine, Russian, Ukrainian

\section{Introduction}

The definition of "bilingualism" was put forward in the middle of the twentieth century by the American scientist Weinreich [1]. Weinreich regards bilingualism as the practice of alternating the use of two languages [2]. Currently, almost a quarter of the world community officially recognize two languages on their territory under the influence of migration, globalization, mass culture, war, the Internet, etc. [3]. Considering the fact that a significant part of the world's population is living in bilingual environment, bilingualism has become one of the research focuses among linguists, ethnologists and cultural scientists. The article focuses on the analysis of bilingualism in Ukraine, namely Ukrainian and Russian, along with the cause and history behind the contemporary language situation in Ukraine.

\section{The Analysis of Bilingualism in Ukraine}

\subsection{The Coexistence of Two Languages in Ukraine}

Ukrainian and Russian are the most commonly spoken languages in Ukraine. 
The census took in 2001 showed that nearly 70 percent of the residents think Russian is not their mother language [4]. Based on a research took in 2008 around Ukraine by Gallup institute, 83 percent of the participants finished the research in Russian. And thus the majority of the people who regard Ukrainian as their native tongue could speak fluent Russian as well. They choose Ukrainian over Russian because of their ethnic identity. Even without being recognized as the official language by state, Russian was considered to be the "official language" in the southern and eastern part of Ukraine from 2012 to 2018. Furthermore, the study of Russian and its culture are secured and promoted by organizations below: Russian Language and Literature Teachers Association in Ukraine, International Russian Language and Literature Teachers Association, Russian Academy in Ukraine, Russian Culture Foundation in Ukraine, The Cultural Creativity Alliance of Russian Journalist and litterateur, etc. Therefore, Ukraine could be regarded as a bilingual country.

\subsection{The Cause of Bilingualism in Ukraine}

\subsubsection{The Loss of Independent Statehood}

Both originated from ancient Russian, Ukrainian and Russian were initially formed along with other dialects in $14^{\text {th }}$ century owning to the separation of East Slav tribe and other states from $9^{\text {th }}$ century to $13^{\text {th }}$ century. In 1720 , a law enacted by Peter I required that all published literature should be written in Russian. Since then, Ukraine had not been promoted under the rule of the tsarist government until the rise of Soviet Union. Even before coming into power, Bolshevik put forward new policies aiming at equal rights for all ethnic minorities. But by the early 1930s, the Leninist national policy gave way to Stalinism, and thus again Ukrainian was stripped off its dominant role by Russian. Therefore, Ukrainian failed to become the official language of the country with the loss of independent statehood.

\subsubsection{Urbanization}

Owning to the rule of the tsarist government, Ukrainian has been regarded as one of the folk languages spoke only among illiteracy and peasants by the beginning of the $19^{\text {th }}$ century. All students in Ukraine were taught in Russian. According to the Public Opinion Foundation (2002), in the regional centers of Ukraine, 75 percent of the population prefer to speak Russian (only 9 percent in favor of Ukrainian), while in rural areas, the majority of the population (65 percent) speak Ukrainian and only 18 percent speaks Russian [5]. Ukraine started its modernization after abolishing the system of slavery followed by the rapid process of urbanization started in the $19^{\text {th }}$ century. In 1930, Soviet was forced into industrialization and collectivization after the establishment of urbanization policies. Later on, the repressive methods had only accelerated the process. By the end of 1940, there were up to 255 cities in Ukraine [6]. With continuous increase in industrialization and urbanization, a growing number of population in city communicated with Russian. 


\subsubsection{Shift of Education}

In 1804, Ukraine established its first Russian college-Haerkof State University, then Saint Vladimir State University in Kiev and Novorossiysk State University in Odessa. Besides, the government replaced Ukrainian with Russian in the education system [7]. Although Ukrainization was once prevalent in 1920s, it went cold by the time when Stalin held power in 1930s. Back then, Russian has entered the compulsory courses in school; and Pravda newspaper, the first Russian newspaper, emerged in Ukraine [8]. At the beginning of 1970s, Ukrainian was no longer a compulsory course, and could be excluded under the written consent of a parent. However, the Ukrainian government has been reconstructing the education system in Ukrainian since the collapse of the Soviet Union in 1991, especially in the central, eastern and southern part of Ukraine [9]. Currently, around 92 percent of students before college are taught in Ukrainian due to the shift of education [10]. Therefore, the people taught before and after the shift of education use Russian and Ukrainian as their mother tongue respectively.

\subsubsection{Repression against the Ukrainian Intelligentsia}

Back in $19^{\text {th }}$ century, the tsarist government called for Russian literature and did not prohibit Ukrainian literature on the premise that they were nothing close to Ukraine's independence. However, all poets and essayist that wrote in Ukrainian were harshly criticized. In the early 1930s, Leninist national politics was replaced by Stalinist, and Ukrainization was quickly replaced by further Russification. Consequently, most representatives of the Ukrainian intelligentsia who were active in the Ukrainization of the 1920s were repressed in the 1930s on account of "bourgeois nationalism" or "nationalist deviation" [11] [12]. In the same period, many Ukrainian writers and poets were repressed, which dealt a great blow to Ukrainian literature and thus paved the way for further Russification of literature in Ukraine. Later on, many books written in Ukrainian were banned and withdrawn from libraries, including the Illustrated History of Ukraine, plays and fairy tales of the Brothers Grimm in Ukrainian [12]. Until recently, Ukrainian literature was brought back into the public eye.

\subsubsection{Migration from Russia to Ukraine}

Except for the policy of Russification, the further dissemination of Russian language in Ukraine is associated with the mass migration from Russia to Ukraine. According to the census in 1989, about 20 percent of the families in Ukraine were built on mixed marriages, mainly Ukrainian-Russian [13]. Furthermore, a survey for Russian conducted in August 1991 showed that 73 percent of the respondents in eastern Ukraine and 62 percent of the respondents living in central and southern regions of Ukraine had close relatives with Ukrainian nationality [14].

\section{Conclusion}

In short, the bilingual phenomenon in Ukraine results from many ways includ- 
ing the loss of independent statehood, urbanization, shift of education, repression against the Ukrainian intelligentsia and migration. In order to build independent and democratic Ukraine, it is essential to establish the position of Ukrainian in ways that achieve high national self-conscience. The findings of this study call for further research on the process of Ukrainization conducted in Ukraine now on account of the effort it took in the past centuries.

\section{Conflicts of Interest}

The author declares no conflicts of interest regarding the publication of this paper.

\section{References}

[1] Weinreich, U. (1953) Languages in Contact: Finlings and Problems. N.Y., 18.

[2] Вайнрайх, В. (1972) Одноязычие и многоязычие//Новое в лингвистике. Языковые контакты.-М.,-Вып. VI.-С. 26.

[3] Жлуктенко Ю.А. Лингвистические аспекты двуязычия. Киев, 1974.

[4] Всеукраинская перепись населения 2001 года. Языковой состав населения Украины.

[5] На Украине русскоязычных больше, чем украиноязычных//Демоскоп Weekly. -18-31 марта 2002. —№ 59-60.

[6] Региональная урбанизация: монография/Г. А. Комарницкая; Львов. гос. фин. акад.-Львов.-Каменец-Подольский: ЛГФА: Медоборы-2006, 2015. -175 с.-Библиогр.: с. 162-175.

[7] Данилевский Г. И. Украинская старина, Харьков, 1866.

[8] Чернышов В. Украинизация как она была Архивировано 16 января 2008 года.

[9] Кучма Л.//Украина-не Россия (книга) «Время», Москва, 2003.

[10] От востока до запада: Где в школах Украины преподают на русском языке.

[11] Magocsi, P.R. (1996) A History of Ukraine. University of Washington Press, Seattle.

[12] Цвілюк, С.А. (2004) Українізація України. Тернистий шлях національно культурного відродження доби сталінізму. «Маяк», Одесса.

[13] Фесенко, В. (2007) Этнорегиональное измерение украинской политики Архивировано 27 сентября 2007 года.

[14] Цитируется по: Фесенко В. Этнорегиональное измерение украинской политики Архивировано 27 сентября 2007 года. 